Review

\title{
Lithium: a key to the genetics of bipolar disorder
}

\author{
Cristiana Cruceanu*, Martin Alda† and Gustavo Turecki*
}

\begin{abstract}
Addresses: *McGill Group for Suicide Studies, Douglas Hospital, McGill University, Montreal, Quebec H4H 1R3, Canada. †Department of Psychiatry, Dalhousie University, Halifax, Nova Scotia B3H 4R2, Canada.

Correspondence: Gustavo Turecki. Email: gustavo.turecki@mcgill.ca
\end{abstract}

\begin{abstract}
Since the 1950s, lithium salts have been the main line of treatment for bipolar disorder (BD), both as a prophylactic and as an episodic treatment agent. Like many psychiatric conditions, BD is genetically and phenotypically heterogeneous, but evidence suggests that individuals who respond well to lithium treatment have more homogeneous clinical and molecular profiles. Response to lithium seems to cluster in families and can be used as a predictor for recurrence of BD symptoms. While molecular studies have provided important information about possible genes involved in BD predisposition or in lithium response, neither the mechanism of action of this drug nor the genetic profile of bipolar disorder is, as yet, completely understood.
\end{abstract}

\section{Introduction}

Lithium has been the treatment of choice for bipolar disorder (BD) for many years. It works particularly well with $\mathrm{BD}$ because it is efficient both as a prophylactic and as an acute treatment; in addition, it has been successfully used as an augmenting agent in the management of unipolar depression. Given the debilitating nature of BD, its lifetime prevalence and significant occurrence in the general population ( 1 to $2 \%$ ), understanding the mode of action of one of its most efficient lines of treatments is critical $[1,2]$.

Lithium can be highly effective, but unfortunately only a subset of patients responds well to this treatment. These patients are distinguishable from non-responders through a number of clinical characteristics that appear to be accounted for, to a certain extent, by the individual's genetic makeup. For instance, BD patients with positive response to lithium typically suffer from a non-rapid cycling course of illness with full remission between episodes [3]. Patients with a family history of lithium-responsive BD among first-degree relatives have a better chance of responding well to lithium [4]. This adds evidence for the heritability of the response to prophylactic treatment with lithium, a fact that can be used in the design of experiments aimed at deciphering the complex etiology of BD as well as the mode of action of lithium treatment.

In this paper, we will review clinical and molecular studies that characterize lithium response in BD families, investigate the molecular underpinnings of $\mathrm{BD}$ by focusing on lithium responders, and identify genes involved in lithium response. Additionally, we will look at the cellular targets of lithium and the genetics behind the side-effects that arise from treatment.

\section{Lithium}

Lithium is a metallic salt most commonly known for its role in treating $\mathrm{BD}$. Though it was first shown to have medical applications in the 1840s, for the treatment of bladder stones and gout, it was not until the late 19th century that the therapeutic effects of lithium in BD became recognized, and its use made mainstream by John Cade in 1949 [5]. Mogens Schou is credited with performing the first series of systematic trials with BD patients during the 1950 s and 1960 s and proving the short-term and prophylactic efficacy of lithium [6]. Lithium has been widely prescribed in the treatment of $\mathrm{BD}$, based on the results of these studies as well as the high success rate approximately $30 \%$ of patients show full response and $60 \%$ show partial response $[2,7,8]$.

In recent decades, the use of lithium has declined in several Western countries, particularly the United States [9,10]. This is probably due to the availability of other treatments on the market as well as concerns about side-effects of lithium, including its narrow therapeutic range. However, in spite of the side-effects, mounting evidence places lithium as one of the most efficient prophylactic interventions for $\mathrm{BD}$ [11].

AMPA, alpha-amino-3-hydroxy-5-methyl-4-isoxazolpropionate; BD, bipolar disorder; cAMP, cyclic adenosine monophosphate; CREB, cyclic adenosine monophosphate response-binding-protein; DGKH, diacylglycerol kinase; GSK3b, glycogen synthase kinase 3-beta; GWAS, genome-wide association study; IMPA, inositol monophosphatase; INPP12, inositol polyphosphate 1-polyphosphatase; NDI, nephrogenic diabetes insipidus; SNP, single nucleotide polymorphism; TORC1, transducer of regulated CREB. 


\section{Heritability of response to lithium}

Like other psychiatric disorders, BD is highly heterogeneous in terms of symptoms and treatment efficacy. Factors shown to lead to disease susceptibility are varied and could be both environmental and genetic. Understanding the molecular biology behind symptoms as well as the mode of action of lithium treatment is important, though complicated in light of the aforementioned heterogeneity. In an effort to refine the BD sub-phenotype, response to lithium treatment has been shown to be a useful characteristic in molecular genetic studies. Lithium responders are identifiable BD patients based on several common attributes, such as episodic course of illness, low rates of co-morbid conditions, absence of rapid cycling, and a family history of BD $[12,13]$. The outcome of treatment can be predicted upon initial presentation of symptoms based on several clinical factors, such as absence of residual symptoms and polarity of the first episode $[3,14,15]$, as well as absence of psychiatric co-morbidity [15]. Conversely, psychiatric co-morbidity predicts poorer response to lithium [14-16]. This sub-phenotype shows greater genetic loading and familial heritability, which led to a variety of studies focusing on the families of patients with positive response to lithium treatment.

Most [17-19], though not all [20-23], of the family studies investigating the relationship between lithium responders and family history of BD have confirmed an association between increased frequency of BD among relatives and positive response to lithium. The stronger genetic loading for BD in lithium responders was first suggested by Mendlewicz et al. in 1973 [24], and later replicated by other studies $[17,25,26]$. These reports have also revealed very low rates of other psychiatric disorders among relatives of lithium-responder patients $[17,19,27]$, and familial clustering was shown by Grof et al. [28]. The mode of inheritance of lithium-responsive BD in families, as reported by Alda et al. [29,30], seems to be autosomal recessive with sex-specific penetrances; relatives of lithium responders are more likely to favorably respond to treatment with lithium should they develop BD symptoms. All of the characteristics mentioned distinguish lithium responders from patients who respond better to other mood stabilizers or who do not respond well to treatment, which strengthens the evidence for a higher genetic loading for this sub-phenotype [19,31-33].

\section{Genetic studies \\ Susceptibility loci}

Linkage studies of BD have identified over 40 chromosomal susceptibility regions [34-44]; however, no clear susceptibility genes were identified through these genome scans, and in fact, meta-analyses showed no statistical significance to support a stronger susceptibility conferred by any one particular locus $[45,46]$. Since the phenotypic heterogeneity of the disorder is probably at fault for the lack of agreement between studies, some groups have resorted to using more homogenous phenotypes - such as lithium response - as a selection criterion. Turecki et al. [27] suggested, in a genome scan of 31 families ascertained through probands with excellent lithium response, that chromosomal regions 15q14 and 7q11.2 could be involved in the pathogenesis of $\mathrm{BD}$. Further analysis according to lithium response suggested that the locus on chromosome 7 may be implicated in lithium response, while the locus on chromosome 15 associates with the BD phenotype [27]. Other studies following a similar pharmacogenetic strategy include a haplotype-sharing analysis involving chromosomal region $18 \mathrm{q} 23$ carried out in a lithium-responsive founder effect population from the Faroe Islands [47], and a study on families from a homogenous population from Saguenay-Lac-St-Jean, Quebec, involving chromosomal region 12q23-q24 [37,48]. In spite of the susceptibility regions found by these studies, no specific genes have been identified as involved in lithium-responsive BD. A strategy in bridging this gap is to correlate broad-scale findings of specific disease-associated loci with lithium's targets in the various cellular pathways.

\section{Genome-wide association studies}

In the era of genome-wide association studies (GWASs), a large variety of loci significant for BD can be found using high-throughput genotyping technology. Recently, the Psychiatric GWAS Consortium has reported having access to 10 GWAS samples available or in preparation for $\mathrm{BD}$, for a total of over 7,000 cases and 10,000 controls [49]. Loci that were most significantly implicated in these association studies are those mapping to or close to genes involved in neurotransmitter transport, biosynthesis and receptor activity, regulation of synaptic transmission, excitability and nervous system development, amino acid metabolism and chemotaxis. These represent approximately 240 genes, but unfortunately most are not replicated between studies $[50,51]$.

Several GWASs have been published to date [52-58], but the majority focused on $\mathrm{BD}$ in general and not lithium response. However, notably in the study by Baum et al. [53], the authors found the strongest result to be related to genetic variation in the diacylglycerol kinase $(D G K H)$ gene, which encodes a key protein in the lithium-sensitive phosphatidyl inositol pathway. An attempt to replicate these findings was recently reported by Squassina et al. [59] in a Sardinian sample of 197 cases and 300 controls: the authors looked specifically for association between three $D G K H$ single nucleotide polymorphisms (SNPs) and the BD phenotype. Additionally, 97 of the cases were characterized as excellent responders to lithium treatment, so association with the lithium-responsive sub-phenotype was also queried. Unfortunately, neither the associations previously shown by Baum et al. [53], nor the expected association with lithium response in $\mathrm{BD}$ could be validated 
by this study. Negative results could be attributed to the lack of power given by a relatively small sample size, as well as phenotypic heterogeneity between different populations [59]. This is particularly true in light of the fact that a similar replication study by Ollila et al. [60] performed in a larger sample size from Finland was able to confirm six SNP associations from the Baum et al. [53] or the Wellcome Trust Case Control Consortium [54] - one of these confirmed associations involved $D G K H$.

In a very recent article, Perlis et al. [61] described the first GWAS of response to lithium in BD. The authors genotyped 1.4 million SNPs in 1,177 BD patients of which 458 were treated with lithium, and further tried to replicate the most significant associations in a second cohort of 359 lithiumresponder BD patients. Though no SNP was significant enough for genome-wide association, the study pointed to several chromosomal regions and candidate genes. Of note is the gene for the glutamate/alpha-amino-3-hydroxy-5methyl-4-isoxazolpropionate (AMPA) receptor, GRIA2 [61], which has previously been shown to be downregulated by chronic lithium treatment in a human neuronal cell line [62]. Though the authors' strategy was inspired, problems such as heterogeneity of sample and gaps in clinical information, as well as a relatively limited sample size should be addressed in order to increase the success of future studies of this nature.

Molecular targets of lithium and candidate-gene studies The phosphoinositide pathway is one of the first and most studied cellular processes where lithium plays an inhibitory role. Berridge et al. first suggested this pathway in what is known as the 'inositol depletion hypothesis' [63,64]. According to this theory, lithium inhibits two enzymes in this pathway: inositol monophosphatase (IMPA) and inositol polyphosphate 1-polyphosphatase (INPP1) [64]. Klein and Melton [65] were the first to identify another target of lithium's inhibitory role in glycogen synthase kinase 3-beta (GSK3b). This enzyme is involved in the Wnt signaling pathway, where its inhibition facilitates $\beta$-catenin's role in promoting the activation of components involved in cell survival [66]. Some studies reported a SNP of the $G S_{3} b$ gene as a source of variability between bipolar patients $[67,68]$, although this was not corroborated by all sources [69]. Interestingly, a study by Adli et al. [70] showed that acutely depressed individuals who were resistant to antidepressant treatment and who were carriers of the $\mathrm{C}$ allele of this SNP responded significantly better to lithium augmentation.

The cAMP (cyclic adenosine monophosphate) pathway is another target of lithium treatment, where the drug has been shown to play a role in regulating CREB (cAMPresponse-binding-protein) activity [71]. Most studies propose that lithium decreases the phosphorylation of CREB, which interferes with expression of the genes regulated by the transcription factor [72-74], while others suggest that lithium also targets the CREB co-activator TORC1 (transducer of regulated CREB) [75]. The cAMP pathway seems to be affected by lithium at additional levels, including the stimulatory G-protein, protein kinase A [76,77], and protein kinase C $[62,78]$.

Additional to these primary pathways of interest, several other candidate genes have been suggested, due to their location downstream of cellular factors regulated by lithium. Amongst them are the gene for phospholipase $\mathrm{C}$ gamma1 (PLCG1) [79], glycophorin A (GYPA) [80], the serotonin transporter gene (SLC6A4) and tryptophan hydroxylase (TPH1) [81,82], as well as genes in the mitochondrial electron transport chain [83].

\section{Gene expression studies Microarrays}

The development of microarray technology has allowed the study of expression patterns for a large number of genes simultaneously, providing invaluable information on gene regulation. Sun et al. [84] investigated the effect of chronic lithium treatment on cultured lymphoblasts from BD patients with excellent lithium response and found several genes that were downregulated when compared to control subjects. Among these were the genes alpha1B-adrenoceptor $(A D R A 1 B)$, acetylcholine receptor protein alpha chain precursor (CHRNA1), cAMP-dependent $3^{\prime}, 5^{\prime}$-cyclic phosphodiesterase $4 \mathrm{D}(P D E 4 D)$, substance P-receptor $(S P R)$, and the ras-related protein RAB7. A microarray profiling study of human neuronal cells after long-term treatment with lithium found that 347 transcripts were upregulated and 324 transcripts were downregulated. Of these, the most significant upregulation was found in peroxiredoxin 2 (PRDX2), encoding an antioxidant enzyme, and the most significant downregulation in tribbles homolog 3 (TRIB3), encoding a pro-apoptotic protein [62]. In a more recent study, Plant et al. [85] took a similar approach by looking at the effect of lithium on gene expression in human neuroblastoma cells. They found that therapeutic levels of lithium caused 14 statistically significant changes in gene expression in the cell line [85].

\section{Model organisms}

Model organisms have recently been used in gene profiling studies in order to elucidate the mode of action of lithium and possibly identify more of its targets. A microarray profiling study of mice subjected to daily lithium intake was reported by McQuillin et al. [86] and found 121 genes to be differentially expressed as a result of lithium treatment. Of these, three genes were most significantly inhibited at the transcriptional level: alanine-glyoxylate aminotransferase 2-like 1 (AGXT2L1), c-mer proto-oncogene tyrosine kinase (MERTK), and sulfotransferase family 1A phenol-preferring member 1 (SULT1A1) [86]. A similar study by Chetcuti et al. [87] identified different genes with 
decreased expression in lithium-treated mice as compared to non-treated animals. Some examples are alpha1 polypeptide (ATP1A1), transcription elongation factor B (SIII)polypeptide 2 (TCEB2), proteasome subunit beta type 5 (PSMB5), and guanine nucleotide binding protein beta1 (GNB1) [87]. In rats, Bosetti et al. [88] found that oral lithium administration at both 7 and 42 days reduced the brain expression of a significant number of genes, many of which code for receptors, protein kinases, transcription and translation factors, and markers of energy metabolism and signal transduction [88].

The studies above did not report consistent results with regard to the genes showing highest differential expression; however, the results overlap in detecting members of the lithium-regulated pathways already discussed earlier in this review. Gene expression profiling studies, such as the ones mentioned here, are essential in addition to GWASs of bipolar disorder patients because they can provide the link between association and causation in disease etiology, as well as response to treatment.

\section{Side-effects of lithium treatment}

As part of the heterogeneity of BD, not all patients respond well to lithium treatment, and even the patients who are positive responders often develop side-effects. Of note are toxic renal effects such as nephrogenic diabetes insipidus (NDI) [89-91], which seem to be mediated through the inhibition of $\mathrm{GSK}_{3} \beta$, one of lithium's best characterized targets [92]. Developmental defects are caused by lithium in invertebrates, as shown in the offspring of rats [93] and mice [94] treated with lithium during pregnancy. In human pregnancies, early reports suggested strong teratogenic effects; however, more recent re-evaluation showed that the effects are dose-dependent and could be lessened by controlling lithium intake during pregnancy and within a short period prior to delivery [95]. Another significant side-effect is weight gain, which has a variety of long-term implications on the wellbeing of the patient [96].

Some studies have looked at side-effects in relation to a possible molecular genetic basis to explain the observed heterogeneity of side-effects between patients. An example is hypothyroidism, seen with long-term treatment, which McQuillin et al. [86] linked to lithium intake at the cellular level by showing that there were changes in mRNA expression in five genes related to thyroxine metabolism. Of these, the most significant were deiodinase $\left(\mathrm{DIO}_{3}\right)$ and thyroid hormone receptor interactor 12 (TRIP12) [86].

Monitoring of patients at the beginning of treatment is very important to ensure correct dosage and to prevent renal problems, but this must be maintained regularly in order to prevent problems that may develop in the long term. Undoubtedly lithium's stabilizing benefits for patients far outweigh the problems. However, in some cases, the inconvenience of side-effects leads to treatment non-compliance, which in turn leads to complete reversal of symptoms and suicidal behavior [97].

\section{Conclusions}

In spite of any side-effects, lithium is still recognized as the most effective prophylactic agent for BD. Moreover, continued treatment with lithium has been associated with a significantly reduced risk of suicide in patients with mood disorders [98], which appears to be unique to this line of treatment. While lithium's positive effect on $\mathrm{BD}$ symptoms is well accepted, the mechanisms leading to this response are only partially understood.

Future studies looking at the cellular pathways that are altered, as well as the genes upstream and downstream of these pathways, will be necessary. While the wealth of BD-related and psychiatric disorder-related research in recent years has identified many targets of lithium at the cellular and molecular levels, even more questions have been raised by these findings. It is clear that patients with positive response to lithium treatment can be separated into a subgroup based on symptoms as well as an increased level of genetic heritability of bipolar-spectrum disorders along first-degree family lines. By elucidating the mechanism of action of lithium and the genetic variants associated with the lithium-response sub-phenotype of $\mathrm{BD}$, we will come closer to understanding disease etiology as a whole. Research focusing on this subgroup of bipolar disorders will be invaluable in the future to devise better treatment for those who do not respond well to lithium or any other drug that is currently available.

\section{Competing interests}

The authors declare that they have no competing interests.

\section{Authors' contributions}

$\mathrm{CC}$ performed the literature review and wrote the manuscript. MA and GT edited and wrote the manuscript.

\section{Acknowledgements}

We thank Laura Fiori and Firoza Mamdani for their assistance with various aspects of the manuscript.

\section{References}

1. Ruzickova M, Turecki G, Alda M: Pharmacogenetics and mood stabilization in bipolar disorder. Am J Med Genet $C$ Semin Med Genet 2003, 123C:18-25.

2. Mamdani F, Groisman IJ, Alda M, Turecki G: Pharmacogenetics and bipolar disorder. Pharmacogenomics J 2004, 4:161-170.

3. Grof P, Alda M, Grof E, Fox D, Cameron P: The challenge of predicting response to stabilising lithium treatment. The importance of patient selection. Br J Psychiatry Suppl 1993, 21:16-19.

4. Grof P: Mood disorders - new definitions, treatment directions, and understanding. Can J Psychiatry 2002, 47:123124.

5. Cade JF: Lithium salts in the treatment of psychotic excitement. Med J Aust 1949, 2:349-352. 
6. Schou M: [Preventive lithium treatment in manic-depressive disease: experiences and progress in recent years.] Nervenarzt 1983, 54:331-339.

7. Baldessarini RJ, Tondo L: Does lithium treatment still work? Evidence of stable responses over three decades. Arch Gen Psychiatry 2000, 57:187-190.

8. Garnham J, Munro A, Slaney C, Macdougall M, Passmore M, Duffy A, O'Donovan C, Teehan A, Alda M: Prophylactic treatment response in bipolar disorder: results of a naturalistic observation study. J Affect Disord 2007, 104:185-190.

9. Young $\mathrm{AH}$, Hammond JM: Lithium in mood disorders: increasing evidence base, declining use? $\mathrm{Br} J$ Psychiatry 2007, 191:474-476.

10. Blanco C, Laje G, Olfson M, Marcus SC, Pincus HA: Trends in the treatment of bipolar disorder by outpatient psychiatrists. Am J Psychiatry 2002, 159:1005-1010.

11. Smith LA, Cornelius V, Warnock A, Bell A, Young AH: Effectiveness of mood stabilizers and antipsychotics in the maintenance phase of bipolar disorder: a systematic review of randomized controlled trials. Bipolar Disord 2007, 9:394-412.

12. Calabrese JR, Fatemi SH, Kujawa M, Woyshville MJ: Predictors of response to mood stabilizers. J Clin Psychopharmacol 1996, 16:24S-31S.

13. Bowden CL: Clinical correlates of therapeutic response in bipolar disorder. J Affect Disord 2001, 67:257-265.

14. Greil W, Kleindienst N, Erazo N, Muller-Oerlinghausen B: Differential response to lithium and carbamazepine in the prophylaxis of bipolar disorder. J Clin Psychopharmacol 1998, 18:455-460.

15. Kusalic M, Engelsmann F: Predictors of lithium treatment responsiveness in bipolar patients. A two-year prospective study. Neuropsychobiology 1998, 37:146-149.

16. Goldberg JF, Garno JL, Leon AC, Kocsis JH, Portera L: A history of substance abuse complicates remission from acute mania in bipolar disorder. J Clin Psychiatry 1999, 60: 733-740.

17. Grof $P$, Alda M, Grof E, Zvolsky P, Walsh M: Lithium response and genetics of affective disorders. J Affect Disord 1994, 32: 85-95.

18. Alda M: Bipolar disorder: from families to genes. Can $J$ Psychiatry 1997, 42:378-387.

19. Passmore MJ, Garnham J, Duffy A, MacDougall M, Munro A, Slaney C, Teehan A, Alda M: Phenotypic spectra of bipolar disorder in responders to lithium versus lamotrigine. Bipolar Disord 2003, 5:110-114.

20. Dunner DL, Fleiss JL, Fieve RR: Lithium carbonate prophylaxis failure. Br J Psychiatry 1976, 129:40-44.

21. Strober M, Morrell W, Burroughs J, Lampert C, Danforth $H$, Freeman R: A family study of bipolar I disorder in adolescence. Early onset of symptoms linked to increased familial loading and lithium resistance. J Affect Disord 1988, 15: 255-268.

22. Engstrom C, Astrom M, Nordqvist-Karlsson B, Adolfsson R, Nylander PO: Relationship between prophylactic effect of lithium therapy and family history of affective disorders. Biol Psychiatry 1997, 42:425-433.

23. Coryell W, Akiskal H, Leon AC, Turvey C, Solomon D, Endicott J: Family history and symptom levels during treatment for bipolar I affective disorder. Biol Psychiatry 2000, 47:1034-1042.

24. Mendlewicz J, Fieve RR, Stallone F: Relationship between the effectiveness of lithium therapy and family history. Am $J$ Psychiatry 1973, 130:1011-1013.

25. Prien RF, Caffey EM Jr, Klett CJ: Factors associated with treatment success in lithium carbonate prophylaxis. Report of the Veterans Administration and National Institute of Mental Health collaborative study group. Arch Gen Psychiatry 1974, 31:189-192.

26. Smeraldi E, Petroccione A, Gasperini M, Macciardi F, Orsini A, Kidd KK: Outcomes on lithium treatment as a tool for genetic studies in affective disorders. J Affect Disord 1984, 6:139-151.
27. Turecki G, Grof P, Grof E, D'Souza V, Lebuis L, Marineau C, Cavazzoni P, Duffy A, Bétard C, Zvolský P, Robertson C, Brewer C, Hudson TJ, Rouleau GA, Alda M: Mapping susceptibility genes for bipolar disorder: a pharmacogenetic approach based on excellent response to lithium. Mol Psychiatry 2001, 6:570-578.

28. Grof P, Duffy A, Cavazzoni P, Grof E, Garnham J, MacDougall M, O'Donovan C, Alda M: Is response to prophylactic lithium a familial trait? J Clin Psychiatry 2002, 63:942-947.

29. Alda M, Grof E, Cavazzoni P, Duffy A, Martin R, Ravindran L, Grof $P$ : Autosomal recessive inheritance of affective disorders in families of responders to lithium prophylaxis? $J$ Affect Disord 1997, 44:153-157.

30. Alda M, Grof P, Grof E, Zvolsky P, Walsh M: Mode of inheritance in families of patients with lithium-responsive affective disorders. Acta Psychiatr Scand 1994, 90:304-310.

31. Soares JC, Gershon S: The lithium ion: a foundation for psychopharmacological specificity. Neuropsychopharmacology 1998, 19:167-182.

32. Swann AC, Bowden CL, Morris D, Calabrese JR, Petty F, Small $\mathrm{J}$, Dilsaver SC, Davis JM: Depression during mania. Treatment response to lithium or divalproex. Arch Gen Psychiatry 1997, 54:37-42.

33. MacQueen GM, Hajek T, Alda M: The phenotypes of bipolar disorder: relevance for genetic investigations. Mol Psychiatry 2005, 10:811-826.

34. Aita VM, Liu J, Knowles JA, Terwilliger JD, Baltazar R, Grunn A, Loth JE, Kanyas K, Lerer B, Endicott J, Wang Z, Penchaszadeh G, Gilliam TC, Baron M: A comprehensive linkage analysis of chromosome 21q22 supports prior evidence for a putative bipolar affective disorder locus. Am J Hum Genet 1999, 64:210-217.

35. Blackwood DH, He L, Morris SW, McLean A, Whitton C, Thomson M, Walker MT, Woodburn K, Sharp CM, Wright AF, Shibasaki Y, St Clair DM, Porteous DJ, Muir WJ: A locus for bipolar affective disorder on chromosome $4 \mathrm{p}$. Nat Genet 1996, 12:427-430.

36. Ewald $\mathrm{H}$, Flint $\mathrm{T}$, Kruse TA, Mors $\mathrm{O}$ : A genome-wide scan shows significant linkage between bipolar disorder and chromosome 12q24.3 and suggestive linkage to chromosomes 1p22-21, 4p16, 6q14-22, 10q26 and 16p13.3. Mol Psychiatry 2002, 7:734-744.

37. Morissette J, Villeneuve A, Bordeleau L, Rochette D, Laberge C, Gagne B, Laprise C, Bouchard G, Plante M, Gobeil L, Shink E, Weissenbach J, Barden N: Genome-wide search for linkage of bipolar affective disorders in a very large pedigree derived from a homogeneous population in quebec points to a locus of major effect on chromosome 12q23q24. Am J Med Genet 1999, 88:567-587.

38. Degn B, Lundorf MD, Wang A, Vang M, Mors O, Kruse TA, Ewald $\mathrm{H}$ : Further evidence for a bipolar risk gene on chromosome 12q24 suggested by investigation of haplotype sharing and allelic association in patients from the Faroe Islands. Mol Psychiatry 2001, 6:450-455.

39. Detera-Wadleigh SD, Badner JA, Berrettini WH, Yoshikawa T, Goldin LR, Turner G, Rollins DY, Moses T, Sanders AR, Karkera JD, Esterling LE, Zeng J, Ferraro TN, Guroff JJ, Kazuba D, Maxwell ME, Nurnberger JI Jr, Gershon ES: A highdensity genome scan detects evidence for a bipolar-disorder susceptibility locus on $13 q 32$ and other potential loci on 1q32 and 18p11.2. Proc Natl Acad Sci USA 1999, 96:56045609 .

40. Badenhop RF, Moses MJ, Scimone A, Mitchell PB, Ewen KR, Rosso A, Donald JA, Adams LJ, Schofield PR: A genome screen of a large bipolar affective disorder pedigree supports evidence for a susceptibility locus on chromosome 13q. Mol Psychiatry 2001, 6:396-403.

41. Berrettini WH, Ferraro TN, Goldin LR, Weeks DE, DeteraWadleigh S, Nurnberger JI Jr, Gershon ES: Chromosome 18 DNA markers and manic-depressive illness: evidence for a susceptibility gene. Proc Natl Acad Sci USA 1994, 91:59185921. 
42. Freimer NB, Reus VI, Escamilla MA, Mclnnes LA, Spesny M, Leon P, Service SK, Smith LB, Silva S, Rojas E, Gallegos A, Meza L, Fournier E, Baharloo S, Blankenship K, Tyler DJ, Batki S, Vinogradov S, Weissenbach J, Barondes SH, Sandkuijl LA: Genetic mapping using haplotype, association and linkage methods suggests a locus for severe bipolar disorder (BPI) at 18q22-q23. Nat Genet 1996, 12:436-441.

43. Kelsoe JR, Spence MA, Loetscher E, Foguet M, Sadovnick AD, Remick RA, Flodman P, Khristich J, Mroczkowski-Parker Z, Brown JL, Masser D, Ungerleider S, Rapaport MH, Wishart WL, Luebbert H: A genome survey indicates a possible susceptibility locus for bipolar disorder on chromosome 22. Proc Natl Acad Sci USA 2001, 98:585-590.

44. Newton JR: Linked gene ontology categories are novel and differ from associated gene ontology categories for the bipolar disorders. Psychiatr Genet 2007, 17:29-34.

45. Badner JA, Gershon ES: Meta-analysis of whole-genome linkage scans of bipolar disorder and schizophrenia. Mol Psychiatry 2002, 7:405-411.

46. Segurado R, Detera-Wadleigh SD, Levinson DF, Lewis CM, Gill $\mathrm{M}$, Nurnberger JI Jr, Craddock N, DePaulo JR, Baron M, Gershon ES, Ekholm J, Cichon S, Turecki G, Claes S, Kelsoe JR, Schofield PR, Badenhop RF, Morissette J, Coon H, Blackwood D, Mclnnes LA, Foroud T, Edenberg HJ, Reich T, Rice JP, Goate A, Mclnnis MG, McMahon FJ, Badner JA, Goldin LR, et al:: Genome scan meta-analysis of schizophrenia and bipolar disorder, part III: Bipolar disorder. Am J Hum Genet 2003, 73:49-62.

47. Ewald H, Wang AG, Vang M, Mors O, Nyegaard M, Kruse TA: A haplotype-based study of lithium responding patients with bipolar affective disorder on the Faroe Islands. Psychiatr Genet 1999, 9:23-34.

48. Shink E, Morissette J, Sherrington R, Barden N: A genomewide scan points to a susceptibility locus for bipolar disorder on chromosome 12. Mol Psychiatry 2005, 10:545-552.

49. Psychiatric GWAS Consortium Steering Committee: A framework for interpreting genome-wide association studies of psychiatric disorders. Mol Psychiatry 2009, 14:10-17.

50. Askland K, Read C, Moore J: Pathways-based analyses of whole-genome association study data in bipolar disorder reveal genes mediating ion channel activity and synaptic neurotransmission. Hum Genet 2009, 125:63-79.

51. Marmol F: Lithium: bipolar disorder and neurodegenerative diseases Possible cellular mechanisms of the therapeutic effects of lithium. Prog Neuropsychopharmacol Biol Psychiatry 2008, 32:1761-1771.

52. Sklar P, Smoller JW, Fan J, Ferreira MA, Perlis RH, Chambert K, Nimgaonkar VL, McQueen MB, Faraone SV, Kirby A, de Bakker PI, Ogdie MN, Thase ME, Sachs GS, Todd-Brown K, Gabriel SB, Sougnez C, Gates C, Blumenstiel B, Defelice M, Ardlie KG, Franklin J, Muir WJ, McGhee KA, Maclntyre DJ, McLean A, VanBeck M, McQuillin A, Bass NJ, Robinson M, et al.: Whole-genome association study of bipolar disorder. Mol Psychiatry 2008, 13:558-569.

53. Baum AE, Akula N, Cabanero M, Cardona I, Corona W, Klemens B, Schulze TG, Cichon S, Rietschel M, Nöthen MM, Georgi A, Schumacher J, Schwarz M, Abou Jamra R, Höfels S, Propping P, Satagopan J, Detera-Wadleigh SD, Hardy J, McMahon FJ: A genome-wide association study implicates diacylglycerol kinase eta (DGKH) and several other genes in the etiology of bipolar disorder. Mol Psychiatry 2008, 13: 197-207.

54. Wellcome Trust Case Control Consortium: Genome-wide association study of 14,000 cases of seven common diseases and 3,000 shared controls. Nature 2007, 447:661-678.

55. Baum AE, Hamshere M, Green E, Cichon S, Rietschel M, Noethen MM, Craddock N, McMahon FJ: Meta-analysis of two genome-wide association studies of bipolar disorder reveals important points of agreement. Mol Psychiatry 2008, 13:466-467.

56. The International Schizophrenia Consortium: Purcell SM, Wray NR, Stone JL, Visscher PM, O'Donovan MC, Sullivan PF, Sklar P, Purcell Leader SM, Ruderfer DM, McQuillin A, Morris DW,
O'Dushlaine CT, Corvin A, Holmans PA, O'Donovan MC, Sklar P; Polygene analyses subgroup, Wray NR, Macgregor S, Sklar $P$, Sullivan PF, O'Donovan MC, Visscher PM; Management committee, Gurling H, Blackwood DH, Corvin A, Craddock NJ, Gill M, Hultman CM, Kirov GK, Lichtenstein P, et al.: Common polygenic variation contributes to risk of schizophrenia and bipolar disorder. Nature 2009, 460:748-752.

57. Scott LJ, Muglia P, Kong XQ, Guan W, Flickinger M, Upmanyu R, Tozzi F, Li JZ, Burmeister M, Absher D, Thompson RC, Francks C, Meng F, Antoniades A, Southwick AM, Schatzberg AF, Bunney WE, Barchas JD, Jones EG, Day R, Matthews K, McGuffin P, Strauss JS, Kennedy JL, Middleton L, Roses AD, Watson SJ, Vincent JB, Myers RM, Farmer AE, Akil H, Burns DK, Boehnke M: Genome-wide association and meta-analysis of bipolar disorder in individuals of European ancestry. Proc Natl Acad Sci USA 2009, 106:7501-7506.

58. Smith EN, Bloss CS, Badner JA, Barrett T, Belmonte PL, Berrettini W, Byerley W, Coryell W, Craig D, Edenberg HJ, Eskin E, Foroud T, Gershon E, Greenwood TA, Hipolito M, Koller DL, Lawson WB, Liu C, Lohoff F, Mclnnis MG, McMahon FJ, Mirel DB, Murray SS, Nievergelt C, Nurnberger J, Nwulia EA, Paschall J, Potash JB, Rice J, Schulze TG, Scheftner W, Panganiban C, Zaitlen N, Zandi PP, Zöllner S, Schork NJ, Kelsoe JR: Genome-wide association study of bipolar disorder in European American and African American individuals. Mol Psychiatry 2009, 14:755-763.

59. Squassina A, Manchia M, Congiu D, Severino G, Chillotti C, Ardau R, Piccardi M, Zompo MD: The diacylglycerol kinase eta gene and bipolar disorder: a replication study in a Sardinian sample. Mol Psychiatry 2009, 14:350-351.

60. Ollila HM, Soronen P, Silander K, Palo OM, Kieseppa T, Kaunisto MA, Lonnqvist J, Peltonen L, Partonen T, Paunio T: Findings from bipolar disorder genome-wide association studies replicate in a Finnish bipolar family-cohort. Mol Psychiatry 2009, 14:351-353.

61. Perlis RH, Smoller JW, Ferreira MA, McQuillin A, Bass $N$, Lawrence J, Sachs GS, Nimgaonkar V, Scolnick EM, Gurling H, Sklar P, Purcell S: A genomewide association study of response to lithium for prevention of recurrence in bipolar disorder. Am J Psychiatry 2009, 166:718-725.

62. Seelan RS, Khalyfa A, Lakshmanan J, Casanova MF, Parthasarathy RN: Deciphering the lithium transcriptome: Microarray profiling of lithium-modulated gene expression in human neuronal cells. Neuroscience 2008, 151:11841197.

63. Berridge MJ: Inositol 1,4,5-trisphosphate-induced calcium mobilization is localized in Xenopus oocytes. Proc $R$ Soc Lond B Biol Sci 1989, 238:235-243.

64. Berridge MJ, Downes CP, Hanley MR: Neural and developmental actions of lithium: a unifying hypothesis. Cell 1989, 59:411-419.

65. Klein PS, Melton DA: A molecular mechanism for the effect of lithium on development. Proc Natl Acad Sci USA 1996, 93: 8455-8459.

66. Detera-Wadleigh SD: Lithium-related genetics of bipolar disorder. Ann Med 2001, 33:272-285.

67. Benedetti F, Bernasconi A, Lorenzi C, Pontiggia A, Serretti A, Colombo C, Smeraldi E: A single nucleotide polymorphism in glycogen synthase kinase 3-beta promoter gene influences onset of illness in patients affected by bipolar disorder. Neurosci Lett 2004, 355:37-40.

68. Benedetti F, Serretti A, Pontiggia A, Bernasconi A, Lorenzi C Colombo $C$, Smeraldi $E$ : Long-term response to lithium salts in bipolar illness is influenced by the glycogen synthase kinase 3-beta -50 T/C SNP. Neurosci Lett 2005, 376:51-55.

69. Szczepankiewicz A, Rybakowski JK, Suwalska A, Skibinska M, Leszczynska-Rodziewicz A, Dmitrzak-Weglarz M, Czerski PM, Hauser J: Association study of the glycogen synthase kinase-3beta gene polymorphism with prophylactic lithium response in bipolar patients. World J Biol Psychiatry 2006, 7: 158-161.

70. Adli M, Hollinde DL, Stamm T, Wiethoff $K$, Tsahuridu M, Kirchheiner J, Heinz A, Bauer M: Response to lithium aug- 
mentation in depression is associated with the glycogen synthase kinase 3-beta -50T/C single nucleotide polymorphism. Biol Psychiatry 2007, 62:1295-1302.

71. Boer U, Cierny I, Krause D, Heinrich A, Lin H, Mayr G, Hiemke $\mathrm{C}$, Knepel W: Chronic lithium salt treatment reduces CRE/ CREB-directed gene transcription and reverses its upregulation by chronic psychosocial stress in transgenic reporter gene mice. Neuropsychopharmacology 2007, 33: 2407-2415

72. Schwaninger M, Blume R, Kruger M, Lux G, Oetjen E, Knepel $\mathrm{W}$ : Involvement of the $\mathrm{Ca}(2+)$-dependent phosphatase calcineurin in gene transcription that is stimulated by cAMP through cAMP response elements. J Biol Chem 1995, 270: 8860-8866.

73. Pham TA, Impey S, Storm DR, Stryker MP: CRE-mediated gene transcription in neocortical neuronal plasticity during the developmental critical period. Neuron 1999, 22:63-72.

74. Kovacs KA, Steullet $P$, Steinmann $M$, Do KQ, Magistretti $P J$, Halfon O, Cardinaux JR: TORC1 is a calcium- and cAMPsensitive coincidence detector involved in hippocampal long-term synaptic plasticity. Proc Natl Acad Sci USA 2007, 104:4700-4705

75. Boer U, Eglins J, Krause D, Schnell S, Schofl C, Knepel W: Enhancement by lithium of cAMP-induced CRE/CREBdirected gene transcription conferred by TORC on the CREB basic leucine zipper domain. Biochem J 2007, 408: 69-77.

76. Schreiber G, Avissar S, Aulakh CS, Murphy DL: Lithiumselective alteration of the function of brain versus cardiac Gs protein. Neuropharmacology 1990, 29:1067-1071.

77. Bezchlibnyk Y, Young LT: The neurobiology of bipolar disorder: focus on signal transduction pathways and the regulation of gene expression. Can J Psychiatry 2002, 47: 135-148.

78. Yildiz A, Guleryuz S, Ankerst DP, Ongur D, Renshaw PF: Protein kinase $C$ inhibition in the treatment of mania: a double-blind, placebo-controlled trial of tamoxifen. Arch Gen Psychiatry 2008, 65:255-263.

79. Turecki G, Grof P, Cavazzoni P, Duffy A, Grof E, Ahrens B, Berghöfer A, Müller-Oerlinghausen B, Dvoráková M, Libigerová E, Vojtechovský M, Zvolský P, Joober R, Nilsson A, Prochazka $H$, Licht RW, Rasmussen NA, Schou M, Vestergaard $P$, Holzinger A, Schumann C, Thau K, Rouleau GA, Alda M: Evidence for a role of phospholipase C-gamma1 in the pathogenesis of bipolar disorder. Mol Psychiatry 1998, 3: 534-538.

80. Alda M, Grof P, Grof E: MN blood groups and bipolar disorder: evidence of genotypic association and Hardy-Weinberg disequilibrium. Biol Psychiatry 1998, 44:361-363.

81. Serretti A, Lilli R, Lorenzi C, Gasperini M, Smeraldi E: Tryptophan hydroxylase gene and response to lithium prophylaxis in mood disorders. J Psychiatr Res 1999, 33: 371-37 7.

82. Serretti A, Lilli R, Mandelli L, Lorenzi C, Smeraldi E: Serotonin transporter gene associated with lithium prophylaxis in mood disorders. Pharmacogenomics J 2001, 1:71-77.

83. Sun X, Wang JF, Tseng M, Young LT: Downregulation in components of the mitochondrial electron transport chain in the postmortem frontal cortex of subjects with bipolar disorder. J Psychiatry Neurosci 2006, 31:189-196.

84. Sun X, Young LT, Wang JF, Grof P, Turecki G, Rouleau GA, Alda M: Identification of lithium-regulated genes in cultured lymphoblasts of lithium responsive subjects with bipolar disorder. Neuropsychopharmacology 2004, 29:799-804.

85. Plant KE, Anderson E, Simecek N, Brown R, Forster S, Spinks J, Toms N, Gibson GG, Lyon J, Plant N: The neuroprotective action of the mood stabilizing drugs lithium chloride and sodium valproate is mediated through the up-regulation of the homeodomain protein Six1. Toxicol Appl Pharmacol 2009, 235:124-134

86. McQuillin A, Rizig M, Gurling HM: A microarray gene expression study of the molecular pharmacology of lithium carbonate on mouse brain mRNA to understand the neurobiology of mood stabilization and treatment of bipolar affective disorder. Pharmacogenet Genomics 2007, 17:605-617.

87. Chetcuti A, Adams LJ, Mitchell PB, Schofield PR: Microarray gene expression profiling of mouse brain mRNA in a model of lithium treatment. Psychiatr Genet 2008, 18:64-72.

88. Bosetti F, Seemann R, Bell JM, Zahorchak R, Friedman E, Rapoport SI, Manickam P: Analysis of gene expression with cDNA microarrays in rat brain after 7 and 42 days of oral lithium administration. Brain Res Bull 2002, 57:205-209.

89. Hestbech J, Hansen HE, Amdisen A, Olsen S: Chronic renal lesions following long-term treatment with lithium. Kidney Int 1977, 12:205-213

90. Markowitz GS, Radhakrishnan J, Kambham N, Valeri AM, Hines WH, D'Agati VD: Lithium nephrotoxicity: a progressive combined glomerular and tubulointerstitial nephropathy. J Am Soc Nephrol 2000, 11:1439-1448.

91. Grunfeld JP, Rossier BC: Lithium nephrotoxicity revisited. Nat Rev Nephrol 2009, 5:270-276.

92. O'Brien WT, Harper AD, Jove F, Woodgett JR, Maretto $S$, Piccolo S, Klein PS: Glycogen synthase kinase-3beta haploinsufficiency mimics the behavioral and molecular effects of lithium. J Neurosci 2004, 24:6791-6798.

93. Klug S, Collins M, Nagao T, Merker HJ, Neubert D: Effect of lithium on rat embryos in culture: growth, development, compartmental distribution and lack of a protective effect of inositol. Arch Toxicol 1992, 66:719-728.

94. Smithberg M, Dixit PK: Teratogenic effects of lithium in mice. Teratology 1982, 26:239-246.

95. Newport DJ, Viguera AC, Beach AJ, Ritchie JC, Cohen LS, Stowe ZN: Lithium placental passage and obstetrical outcome: implications for clinical management during late pregnancy. Am J Psychiatry 2005, 162:2162-2170.

96. Torrent C, Amann B, Sanchez-Moreno J, Colom F, Reinares M Comes M, Rosa AR, Scott J, Vieta E: Weight gain in bipolar disorder: pharmacological treatment as a contributing factor. Acta Psychiatr Scand 2008, 118:4-18.

97. Franks MA, Macritchie KA, Mahmood T, Young AH: Bouncing back: is the bipolar rebound phenomenon peculiar to lithium? A retrospective naturalistic study. J Psychopharmacol 2008, 22:452-456.

98. Cipriani A, Pretty H, Hawton K, Geddes JR: Lithium in the prevention of suicidal behavior and all-cause mortality in patients with mood disorders: a systematic review of randomized trials. Am J Psychiatry 2005, 162:1805-1819.

Published: 19 August 2009

doi:10.1186/gm79

(c) 2009 BioMed Central Ltd 